Michał Broniszewski

Uniwersytet Wrocławski

\title{
Znaczenie zintegrowanego podejścia do obszarów funkcjonalnych w ujęciu regionalnym - studium przypadku
}

DOI: $10.19195 / 1643-0328.23 .12$

Słowa kluczowe: zintegrowane podejście, rozwój obszarów funkcjonalnych, polityka regionalna Unii Europejskiej

\section{Wprowadzenie}

Rosnące znaczenie zintegrowanego podejścia do rozwoju obszaru funkcjonalnego stało się przyczyną poszukiwań nowych rozwiązań, sprzyjających polityce regionalnej Unii Europejskiej (UE) w zakresie rozwoju terytorialnego. Obecnie, w celu rozwoju kluczowych obszarów funkcjonalnych, należy skupić się na wdrażaniu innowacyjnych rozwiązań stymulujących. Stanowi to istotne wyzwanie we współczesnej polityce regionalnej UE. Zarówno władze państwowe, jak i jednostki samorządu terytorialnego (JST) stają więc przed koniecznością wdrażania i realizacji nowych instrumentów polityki regionalnej UE w kolejnej perspektywie finansowej na lata 2014-2020, w celu zrealizowania strategii Europa 2020. Takim instrumentem są Zintegrowane Inwestycje Terytorialne (ZIT), których zadaniem jest wspieranie wdrożenia koncepcji zintegrowanego podejścia ukierunkowanego terytorialnie w polityce regionalnej UE (integrated territorial approach). Podejście zintegrowane koncentruje się głównie na konsolidowaniu działań publicznych tak, by służyły one rozwojowi obszarów funkcjonalnych oraz spójności terytorialnej. Koncepcja nowego podejścia w polityce regionalnej UE uwzględnia wykorzystanie własnych potencjałów (zasobów) terytorialnych określonych funkcjonalnie, integrację działań publicznych w wymiarze przestrzennym oraz wielopoziomowy system zarządzania.

Celem niniejszej pracy jest ukazanie koncepcji zintegrowanych działań publicznych na rzecz rozwoju obszarów funkcjonalnych. W artykule zdefiniowano obszar funkcjonalny oraz wskazano na znaczenie, jakiego zintegrowane podejście nabrało $\mathrm{w}$ polityce regionalnej UE po $2014 \mathrm{r}$. W ramach analizy porównawczej określono również model idealny poprzez zastosowanie modelu Weberowskiego dla wdrażania ZIT w województwie opolskim. 


\section{Istota zintegrowanego podejścia do rozwoju obszarów funkcjonalnych}

Istotą koncepcji badań nad znaczeniem zintegrowanego podejścia do rozwoju regionalnego jest zastosowanie (w ramach polityki regionalnej) zestawu zharmonizowanych działań ukierunkowanych na tzw. obszary funkcjonalne charakteryzujące się wspólnymi geograficznymi, społeczno-gospodarczymi i przestrzennymi cechami. Nowy paradygmat wspierania rozwoju regionu odchodzi od regionów administracyjnych i koncentruje się na wyodrębnieniu regionu funkcjonalnego jako przedmiotu polityki regionalnej.

W grudniu 2013 r. Rada Unii Europejskiej formalnie przyjęła nowe zasady i przepisy dotyczące unijnej polityki spójności na lata 2014-2020. Po raz pierwszy definicja zintegrowanego podejścia do obszarów funkcjonalnych pojawiła się w dokumentacji Komisji Europejskiej $(\mathrm{KE})^{1}$. Natomiast pojęcie obszaru funkcjonalnego, jako elementu polityki regionalnej, zostało określone dopiero na poziomie krajowym - w Krajowej Strategii Rozwoju Regionalnego 2010-2020: Regiony-Miasta-Obszary Wiejskie (KSRR). Przyjęta $\mathrm{w}$ ramach KSRR definicja obszaru funkcjonalnego jest zgodna $\mathrm{z}$ założeniami terminologicznymi Koncepcji Przestrzennego Zagospodarowania Kraju 2030 (KPZK 2030). Dodatkowo ustawa $\mathrm{z}$ dnia 27 marca 2003 r. o planowaniu i zagospodarowaniu przestrzennym (Dz.U. z 2012 r. poz. 647, poz. 951 i poz. 1445 oraz z 2013 r. poz. 21 i poz. 405), sprowadzając obszary funkcjonalne do pojęcia obszaru problemowego, doprecyzowuje definicję obszaru funkcjonalnego występującego w KPZK 2030 jako usystematyzowanie obszarów funkcjonalnych na poziomie krajowym. Za obszar funkcjonalny, zgodnie $\mathrm{z}$ ustawą, uznaje się obszar szczególnego zjawiska z zakresu gospodarki przestrzennej lub występowanie konfliktów przestrzennych, wskazywane w planie zagospodarowania przestrzennego województwa lub określone w studium uwarunkowań i kierunków zagospodarowania przestrzennego gminy ${ }^{2}$.

KPZK 2030 rozbudowuje tę definicję i przekształca ją w „zwarty układ przestrzenny, składający się z funkcjonalnie powiązanych terenów, charakteryzujących się wspólnymi uwarunkowaniami i przewidywanymi, jednolitymi celami rozwoju"3. Definicja KPZK 2030 ustala pewną systematykę obszarów funkcjonalnych i określa ich podstawowe cechy. Obszary funkcjonalne obejmują zatem następujące kategorie, których wyznaczanie wynika z obowiązujących ustaw (ustawy doprecyzowują definicje tych obszarów) ${ }^{4}$ :

- obszar metropolitalny — „obszar wielkiego miasta oraz powiązanego $\mathrm{z}$ nim funkcjonalnie bezpośredniego otoczenia, ustalony w koncepcji przestrzennego zagospodarowania kraju";

${ }^{1}$ Zintegrowane działania na rzecz zrównoważonego rozwoju obszarów miejskich. Polityka spójności na lata 2014-2020, Bruksela 2014.

${ }^{2}$ Ustawa z dnia 27 marca 2003 r. o planowaniu i zagospodarowaniu przestrzennym (Dz.U. z 2012 r. poz. 647, poz. 951 i poz. 1445 oraz z 2013 r. poz. 21 i poz. 405).

${ }^{3}$ Koncepcja Przestrzennego Zagospodarowania Kraju 2030, dokument przyjęty przez Radę Ministrów 13 grudnia 2011 r., s. 159.

4 Ibidem. 
- tereny zamknięte - ustalane na zasadach określonych ustawą Prawo geodezyjne i kartograficzne z 17 maja 1989 r., tereny o charakterze zastrzeżonym ze względu na obronność i bezpieczeństwo państwa ${ }^{5}$;

- strefa ochronna terenu zamkniętego - obszar, na którym, z uwagi na potrzeby obronności lub bezpieczeństwa państwa, wprowadza się ograniczenia w zagospodarowaniu lub korzystaniu z terenów;

- obszar przestrzeni chronionej - obszar planowany do ochrony przed zabudową niezwiązaną z celami ochrony i udostępnianiem terenów chronionych wraz z otulinami i korytarzami ekologicznymi, strefy ochronne ujęć wody i zbiorników wód śródlądowych, obszary objęte ochroną zabytków i opieką nad zabytkami oraz tereny zieleni, zadrzewień, lasów i upraw polowych ${ }^{6}$.

W obliczu współczesnych wyzwań polityki regionalnej UE oraz konieczności stosowania bardziej precyzyjnych i skutecznych metod oddziaływania na zjawiska i trendy wewnątrzregionalne, zintegrowane podejście do rozwoju obszarów funkcjonalnych nabrało szczególnego znaczenia w polityce spójności UE po 2014 r. ${ }^{7}$ Konsekwencją wyodrębniania obszarów funkcjonalnych jako przedmiotów polityki regionalnej UE po 2014 jest właśnie wyodrębnienie instrumentów organizacyjno-finansowych, jakimi są obecnie ZIT. Wskazaniem umocowania ZIT w prawie unijnym są dokumenty regulujące wdrażanie ZIT w UE:

- Rozporządzenie Parlamentu Europejskiego i Rady (UE) 1303/2013 z dnia 17 grudnia 2013 r., które w art. 36 reguluje wdrażanie ZIT na poziomie unijnym. Przepisy unijne stanowią podstawę tworzenia i realizacji programów na lata 2014-2020

- Rozporządzenie Parlamentu Europejskiego i Rady (UE) nr 1301/2013 z dnia 17 grudnia 2013 r., rozdział II, art. $7^{9}$.

- Rozporządzenie Parlamentu Europejskiego i Rady (UE) nr 1304/2013 z dnia 17 grudnia 2013 r. ${ }^{10}$ Przepisy unijne stanowią wkład w realizację strategii Europa 2020 $\mathrm{w}$ celu osiągania inteligentnego i zrównoważonego wzrostu gospodarczego ${ }^{11}$.

${ }^{5}$ Ustawa z dnia 17 maja 1989 r. Prawo geodezyjne i kartograficzne (Dz.U. z 2005 r. Nr 240, poz. 2027, z późn. zm.).

${ }^{6}$ Koncepcja Przestrzennego Zagospodarowania Kraju 2030..., s. 159.

7 Rozporządzenie Parlamentu Europejskiego i Rady (UE) 1303/2013 z dnia 17 grudnia 2013 r. ustanawiające wspólne przepisy dotyczące Europejskiego Funduszu Rozwoju Regionalnego, Europejskiego Funduszu Społecznego, Funduszu Spójności, Europejskiego Funduszu Rolnego na rzecz Rozwoju Obszarów Wiejskich oraz Europejskiego Funduszu Morskiego i Rybackiego oraz ustanawiające przepisy ogólne dotyczące Europejskiego Funduszu Rozwoju Regionalnego, Europejskiego Funduszu Społecznego, Funduszu Spójności i Europejskiego Funduszu Morskiego i Rybackiego oraz uchylające rozporządzenie Rady (WE) nr 1083/2006.

8 Oficjalna strona funduszy strukturalnych: https://www.funduszeeuropejskie.gov.pl/strony/o-funduszach/dokumenty/rozporzadzenie-parlamentu-europejskiego-i-rady-ue-nr-13032013-z-dnia-17-grudnia2013-roku-ustanawiajace-wspolne-przepisy-dotyczace-efrr-efs-fs-effrow-oraz-efmir/ (dostęp: 26 lutego 2017).

9 Rozporządzenie Parlamentu Europejskiego i Rady (UE) nr 1301/2013 z dnia 17 grudnia 2013 r. w sprawie Europejskiego Funduszu Rozwoju Regionalnego i przepisów szczególnych dotyczących celu „Inwestycje na rzecz wzrostu i zatrudnienia" oraz w sprawie uchylenia rozporządzenia (WE) nr 1080/2006.

10 Rozporządzenie Parlamentu Europejskiego i Rady (UE) nr 1304/2013 z dnia 17 grudnia 2013 r. w sprawie Europejskiego Funduszu Społecznego i uchylające rozporządzenie Rady (WE) nr 1081/2006.

11 Europa 2020. Strategia na rzecz inteligentnego i zrównoważonego rozwoju sprzyjającego włączeniu społecznemu, KOM (2010) 2020 wersja ostateczna, Komisja Europejska, Bruksela, 3.3.2010, s. 11. 


\section{Analiza uwarunkowań organizacyjnych i instytucjonalnych wdrażania zintegrowanego podejścia do rozwoju obszarów funkcjonalnych w Polsce}

Zintegrowane podejście ma kluczowe znaczenie dla obszarów zapaści społeczno-gospodarczej, w których wciąż aktualne i przenikające się problemy związane z degradacją obszarów funkcjonalnych blokują rozwój i aktywność. Zidentyfikowane obszary funkcjonalne (problemowe) oraz endogeniczne potencjały zostały ostatecznie zapisane w krajowych i regionalnych dokumentach strategicznych wdrażających politykę spójności UE w Polsce. Podejście to wynika z założeń prowadzonej polityki regionalnej UE, czego wyrazem są regulacje prawne w Polsce ${ }^{12}$. Artykuł 30 ustawy z dnia 11 lipca 2014 r. o zasadach realizacji programów w zakresie polityki spójności finansowanych w perspektywie finansowej 2014-2020 określa, iż ZIT są instrumentem rozwoju terytorialnego, o którym mowa w art. 36 rozporządzenia ogólnego oraz $\mathrm{w}$ art. 7 rozporządzenia Europejskiego Funduszu Rozwoju Regionalnego (EFRR). Ustawodawca postrzega ZIT jako instrument mający wpływ na rozwój i wzrost spójności terytorialnej. Ustawodawca określa również realizację ZIT w ramach regionalnego programu operacyjnego ZIT:

- są realizowane na terenie miast będących siedzibą władz samorządu województwa lub wojewody i obszarów powiązanych z nimi funkcjonalnie;

- mogą być realizowane na terenie innych miast i obszarów powiązanych z nimi funkcjonalnie - wyznaczonych zgodnie z warunkami określonymi w umowie partnerstwa;

- są realizowane przez wyodrębnione działania lub poddziałania $w$ ramach co najmniej dwóch osi priorytetowych regionalnego programu operacyjnego finansowanych $\mathrm{z}$ dwóch funduszy strukturalnych;

- są zarządzane przez związek ZIT utworzony w formach współpracy JST, o których mowa w ustawie z dnia 8 marca 1990 r. o samorządzie gminnym (Dz.U. z 2013 r. poz. 594, z późn. zm.), albo przez JST na podstawie umowy lub porozumienia o współpracy w celu wspólnej realizacji ZIT zawartych pomiędzy JST położonymi na obszarze realizacji ZIT, na zasadach określonych w umowie albo porozumieniu ${ }^{13}$.

Istotą ustawy jest wskazanie warunków realizacji ZIT:

- powołanie związku ZIT albo zawarcie umowy lub porozumienia, o których mowa w ust. 4, pomiędzy JST położonymi na obszarze realizacji ZIT, określonym przez zarząd województwa w regionalnym programie operacyjnym;

- opracowanie strategii przez podmioty, o których mowa w ust. 4 strategii ZIT, w art. 7 rozporządzenia EFRR i art. 12 rozporządzenia Europejskiego Funduszu Społecznego (EFS), oraz jej pozytywne zaopiniowanie w terminie 60 dni od dnia jej otrzymania przez:

12 Ustawa z dnia 11 lipca 2014 r. o zasadach realizacji programów w zakresie polityki spójności finansowanych w perspektywie finansowej 2014-2020 (Dz.U. z 2014 r. poz. 1146); Zasady Realizacji Zintegrowanych Inwestycji Terytorialnych $w$ Polsce, Warszawa 2013.

13 Artykuł 30 pkt 2 ustawy z dnia 11 lipca 2014 r. o zasadach realizacji programów w zakresie polityki spójności finansowanych w perspektywie finansowej 2014-2020. 
a) instytucję zarządzającą regionalnym programem operacyjnym - w zakresie możliwości finansowania ZIT w ramach tego programu,

b) ministra właściwego do spraw rozwoju regionalnego wykonującego zadania państwa członkowskiego - w zakresie zgodności z umową partnerstwa oraz możliwości finansowania projektów, o których mowa w ust. 7, z krajowych programów operacyjnych, jeżeli strategia ZIT to przewiduje,

c) zawarcie porozumienia lub umowy dotyczących realizacji ZIT pomiędzy podmiotami, o których mowa w ust. 4, a właściwą instytucją zarządzającą, zawierających w szczególności zakres powierzonych zadań, obejmujących co najmniej udział podmiotów, o których mowa w ust. 4, w wyborze projektów do dofinansowania przez właściwą instytucję zarządzającą regionalnym programem operacyjnym oraz współpracę z tą instytucją przy przygotowywaniu kryteriów wyboru projektów dla wyodrębnionych działań lub poddziałań służących realizacji $\mathrm{ZIT}^{14}$.

Realizacja ZIT w obszarach funkcjonalnych regionów Polski odbywa się według następującego modelu organizacyjnego: powołanie Związku ZIT (powołanie zinstytucjonalizowanej formy partnerstwa), przygotowanie strategii ZIT, posiadanie odpowiedniej zdolności instytucjonalnej, podpisanie porozumienia dotyczącego realizacji ZIT w województwie pomiędzy Związkiem ZIT a instytucją zarządzającą regionalnym programem operacyjnym, zawarcie stosownych zapisów w regionalnych programach operacyjnych (spełniających wymogi KE oraz zgodnych z zapisami partnerskimi w celu wspólnej realizacji porozumień zawartych pomiędzy JST położonymi na obszarze realizacji ZIT). Końcowym warunkiem wdrożenia ZIT jest przeznaczenie na realizację środków z podstawowej alokacji regionalnego programu operacyjnego, jako uzupełnienia środków pochodzących z rezerwy programowej, oraz możliwość uzyskania dofinansowania na realizację projektów komplementarnych z zakresu gospodarki niskoemisyjnej, w zależności od ustaleń z KE ${ }^{15}$.

Działania podejmowane przez ZIT w regionach polskich zostały zawarte w Zasadach Realizacji Zintegrowanych Inwestycji Terytorialnych w Polsce, a przygotowane przez ówczesne Ministerstwo Rozwoju Regionalnego (obecnie Ministerstwo Rozwoju). Miały one przyczyniać się do:

- sprzyjania rozwojowi współpracy i integracji na obszarach funkcjonalnych największych polskich miast,

- promowania partnerskiego modelu współpracy różnych jednostek administracyjnych na miejskich obszarach funkcjonalnych,

- realizacji zintegrowanych projektów odpowiadających w sposób kompleksowy na potrzeby i problemy miast $\mathrm{i}$ ich obszarów funkcjonalnych,

- zwiększania wpływu miast i powiązanych $\mathrm{z}$ nimi obszarów funkcjonalnych na kształt i sposób realizacji działań wspieranych na ich obszarze w ramach polityki spójności ${ }^{16}$.

\footnotetext{
${ }^{14}$ Ibidem.

15 Regionalne Programy Operacyjne na lata 2014-2020.

${ }^{16}$ Zasady Realizacji Zintegrowanych Inwestycji Terytorialnych $w$ Polsce..., s. 4.
} 
Rozwój obszarów funkcjonalnych w regionach Polski jest nieodzowną determinantą rozwoju endogenicznego, gdyż bazuje on również na własnych regionalnych zasobach ${ }^{17}$. Dlatego też jednym z założeń przy wdrażaniu ZIT w Polsce jest pobudzanie wzrostu endogenicznego przy wykorzystaniu potencjału zasobów danego obszaru funkcjonalnego. Zasadność wyodrębniania obszarów funkcjonalnych w regionie jest zdeterminowana faktem, że mogą mieć one inne niż pozostała część regionu cechy charakterystyczne, które wpływają na jego rozwój. ZIT mają zatem wspierać i pobudzać rozwój w ramach obszarów, które do tej pory traktowane były tak samo, jak całość regionu administracyjnego, i nie wykorzystały swojego potencjału, gdyż jest on specyficzny dla różnych obszarów funkcjonalnych w regionach Polski.

\section{Model wdrażania Zintegrowanych Inwestycji Terytorialnych w wybranym regionie (studium przypadku)}

W odniesieniu do teorii koncepcji rozwoju regionalnego model wdrażania ZIT opiera się na podejściu zintegrowanym ${ }^{18}$. To właśnie ten nowy paradygmat polityki regionalnej ukierunkowanej terytorialnie ma się przyczynić do rozwoju obszarów funkcjonalnych w poszczególnych regionach, będąc elementem polityki regionalnej prowadzonej przez podmioty państwowe (w tym regionalne), które określają obecny zakres działań w tej dziedzinie ${ }^{19}$. W Polsce prowadzona jest polityka zrównoważonego rozwoju i ma ona wpływ na model wdrażania ZIT oraz na samą politykę regionalną. Jest ona wpisana $\mathrm{w}$ art. 2 ustawy z dnia 6 grudnia 2006 r. o zasadach prowadzenia polityki rozwoju ${ }^{20}$. Ustawodawca poprzez politykę rozwoju rozumie zespół wzajemnie powiązanych działań podejmowanych i realizowanych $\mathrm{w}$ celu zapewnienia trwałego i zrównoważonego rozwoju kraju oraz spójności społeczno-gospodarczej i terytorialnej, w skali krajowej, regionalnej lub lokalnej. W nowym okresie programowania polityka regionalna na lata 2014-2020 określa formy pobudzania i kierowania obszarami funkcjonalnymi poprzez zintegrowane podejście do działań na rzecz zwiększania wpływu miast i ich obszarów funkcjonalnych na kształt i sposób realizacji strategii rozwoju zrównoważonego na ich obszarze $^{21}$. Nowością jest zmiana paradygmatu prowadzonej polityki regionalnej z systemowego na zintegrowany, co umożliwia tworzenie ZIT i wspomaganie rozwoju obszarów funkcjonalnych. Obszary te mogą się jednak różnić uwarunkowaniami w rozwoju, co jest skutkiem odmiennej sytuacji społeczno-gospodarczej w poszczególnych

17 P. Aghion, P. Howitt, Endogenous Growth Theory, Cambridge, 1997.

18 E. Szafranek, Zintegrowane inwestycje terytorialne jako narzędzie budowy potencjału obszarów funkcjonalnych. Przykład Kędzierzyńsko-Kozielskiego Subregionalnego Obszaru Funkcjonalnego, „Gospodarka Regionalna w Teorii i Praktyce" 2015, nr 392, s. 111.

19 Z. Strzelecki, Gospodarka regionalna i lokalna, Warszawa 2009, s. 81-86.

20 Dz.U. 2006 Nr 227, poz. 1658.

21 F. Barca, Program dla zreformowanej polityki spójności. Podejście ukierunkowane terytorialnie w osiąganiu celów i oczekiwań Unii Europejskiej, Warszawa 2013, s. 19. 
regionach ${ }^{22}$. Analizując odmienność kształtowania i poziomu rozwoju obszarów funkcjonalnych, zauważyć można, na przykładzie wdrażania opolskiego ZIT, zróżnicowanie wewnątrzregionalne. $\mathrm{W}$ województwie opolskim instrument ZIT realizowany jest na obszarze aglomeracji opolskiej ${ }^{23}(\mathrm{AO})$. Z uwagi na zróżnicowanie cech przestrzenno-funkcjonalnych w obrębie obszaru AO zaproponowano wydzielenie obszaru rdzeniowego (miasto Opole), strefy wewnętrznej i strefy zewnętrznej ${ }^{24}$.

Jako rdzeń AO zdefiniowano miasto Opole. Zwarte związki funkcjonalne (społeczno-gospodarcze i morfologiczne) z rdzeniem wykazuje wewnętrzny obszar aglomeracji, odpowiadający konsekwentnie obszarowi wyznaczonemu w ekspertyzie wykonanej na zlecenie ówczesnego Ministerstwa Rozwoju Regionalnego. W skład tego obszaru wchodzi 12 gmin: Chrząstowice, Dąbrowa, Dobrzeń Wielki, Komprachcice, Lewin Brzeski, Łubniany, Niemodlin, Prószków, Tarnów Opolski, Tułowice, Turawa oraz Ozimek. Strefa zewnętrzna AO obejmuje łącznie 8 gmin, w tym 2 gminy północnej części powiatu opolskiego (Murów, Popielów), 5 gmin powiatu krapkowickiego oraz gminę Izbicko z powiatu strzeleckiego. Gminy te w obszarze AO pełnią istotne funkcje: bądź to przyrodnicze (zapewniając mieszkańcom aglomeracji niezbędny zasób terenów rekreacyjno-wypoczynkowych), bądź to wzmacniające potencjał społeczno-gospodarczy obszaru ${ }^{25}$.

Diagnoza obszaru wsparcia w ramach strategii opolskiego ZIT uwypukla źródła wyzwań, przed jakimi staje obszar AO, co zostało podzielone na kategorie (zawierające wnioski z diagnozy i rekomendacje):

- Demografia - poprzez działania zintegrowane, co ma przyczynić się do stymulowania wzrostu gospodarczego, wspierającego powstawanie nowych miejsc pracy, oraz poprzez wzrost jakości życia czy rozwój usług publicznych świadczonych przez samorządy AO. Główny nacisk kładziony jest na proces depopulacji, będący centralnym zagadnieniem oraz wyzwaniem stojącym przed integralnie rozumianym obszarem funkcjonalnym AO. Stanowi to punkt wyjścia w kontekście zintegrowanej, wielopłaszczyznowej interwencji publicznej instrumentu ZIT.

- Gospodarka - poprzez rozwój atrakcyjności inwestycyjnej AO. Za pomocą wdrażania nowoczesnych rozwiązań opartych na technologiach przyjaznych środowisku zwiększanie zintegrowanych działań podnoszących atrakcyjność gospodarczą przyczynia się do wzrostu jakości zasobów pracy i kapitału ludzkiego. ZIT opolski ma wspomagać rozwój gospodarczy AO poprzez zwiększenie liczby projektów o charakterze badawczo-rozwojowym czy tworzenie innowacji w sektorze $(\mathrm{B}+\mathrm{R})^{26}$.

- Rynek Pracy - działania na rzecz tworzenia nowych miejsc pracy o wysokiej jakości, a także dostosowanie systemu kształcenia do potrzeb gospodarki wolnorynkowej. Wzmacnianie atrakcyjności gospodarczej przez opolski ZIT wspomaga poprawę

22 A. Dumała, Regiony międzynarodowe - synteza porównawcza, [w:] Regiony w stosunkach międzynarodowych, red. I. Topolski et al., Lublin 2009, s. 263.

23 Strategia Zintegrowanych Inwestycji Terytorialnych Aglomeracji Opolskiej, Opole 2015, s. 10.

24 Ibidem, s. 21.

${ }^{25}$ Ibidem.

26 G. Gorzelak, M. Kozak, Regionalny wymiar strategicznego programowania rozwoju, [w:] Zarządzanie strategiczne rozwojem, red. J. Górniak, S. Mazur, Warszawa 2012, s. 138. 
sytuacji na rynku pracy. Instrument ZIT umożliwia rozwój powiązań funkcjonalnych obszarów społecznych i gospodarczych AO.

- Edukacja - poprzez zintegrowanie działań na rzecz rozwoju dostępu do edukacji, w tym przedszkolnej, likwidowania wewnętrznych zróżnicowań w dostępności edukacji przedszkolnej (przykładem może być zapisanie dziecka do publicznego przedszkola $\mathrm{w}$ gminie zamieszkania). ZIT będzie także wspomagał niwelowanie dysproporcji wewnętrznych AO pomiędzy gminami miejskimi i miejsko-wiejskimi. W obszarze edukacji ZIT funkcjonujący na obszarze AO będzie podejmował działania dostosowawcze w zakresie programu kształcenia, uwzględniając potrzeby inwestorów w zakresie współpracy przy realizacji praktyk zawodowych oraz staży w zakładach pracy, a także przy wdrażaniu zintegrowanego systemu transportu.

- Infrastruktura techniczna - poprzez działania zintegrowane, wzmacniające jej cechy, takie jak struktura, lokalizacja czy jakość, co ma duże znaczenie dla rozwoju społeczno-gospodarczego AO. W kontekście poprawy jakości życia mieszkańców AO oraz jakości stanu środowiska rekomendowane jest podejmowanie działań zmierzających do dalszego rozwoju sieci kanalizacyjnych, gazowych i ciepłowniczych, przez co opolski ZIT wspomaga likwidację dysproporcji między terenami miejskimi a wiejskimi.

- Dostępność transportowa - poprzez rozwój zintegrowanych systemów komunikacji, wzmocnienie powiązań funkcjonalnych, zarówno wewnątrz AO, jak i na obszarach zewnętrznych. Działania takie mogą przyczynić się do poprawy dostępności komunikacyjnej, np. w północnej części AO, w gminach o niekorzystnej sytuacji komunikacyjnej. Zewnętrzna dostępność komunikacyjna aglomeracji jest znacznie lepsza niż dostępność wewnętrzna.

— Środowisko - wskazane jest rozwijanie ekologicznych, przyjaznych środowisku form transportu, rozwój systemu publicznego transportu zbiorowego bazującego na taborze odpowiadającym wymogom współczesnych norm ekologicznych, wyprowadzanie ruchu samochodowego $\mathrm{z}$ centrum miast, edukacja ekologiczna, a także działania zmniejszające energochłonność sektora publicznego oraz mieszkaniowego.

- Turystyka i dziedzictwo kulturowe - budowanie trwałych i efektywnych powiązań funkcjonalnych (opierających się na rzeczywistych i zidentyfikowanych potencjałach). Należy zwrócić uwagę na kwestię budowy zintegrowanego systemu transportowego, uwzględniającego sieć tras i ścieżek rowerowych. W kontekście funkcjonowania obszarów atrakcyjnych przyrodniczo (wykorzystywanych turystycznie) ważne są działania ukierunkowane na wdrażanie nowoczesnych technologii przyjaznych środowisku ${ }^{27}$.

Wskazana diagnoza obszarów problemowych AO stanowi wymiar realizacji i działania zintegrowanego podejścia $w$ ramach strategii opolskiego ZIT i staje się kluczowym elementem determinującym specyfikę wykorzystania instrumentu opolskiego ZIT i jego wymiaru terytorialnego. Pierwszą podstawową determinantą określającą zakres interwencji strategii ZIT są uwarunkowania zawarte w Regionalnym Programie Operacyjnym Województwa Opolskiego na lata 2014-2020 (zakres działań), gdzie podkreślono, że interwencja dedykowana ZIT koncentruje się na:

\footnotetext{
27 Ibidem, s. 26-34.
} 
- przygotowaniu terenów inwestycyjnych w AO (OP II),

- efektywności energetycznej w budynkach publicznych AO, strategiach niskoemisyjnych (OP III),

- wsparciu dziedzictwa kulturowego i kultury w AO (OP V),

- wsparciu edukacji przedszkolnej, kształcenia ogólnego i zawodowego w AO (OP IX) ${ }^{28}$.

Na rysunku 1 zaprezentowano modelowe ujęcie działań realizowanych przez opolski ZIT, przy pomocy opisu organizacyjnego, z wykorzystaniem modelu Weberowskiego i z uwzględnieniem przedstawionych obszarów problemowych występujących w AO.

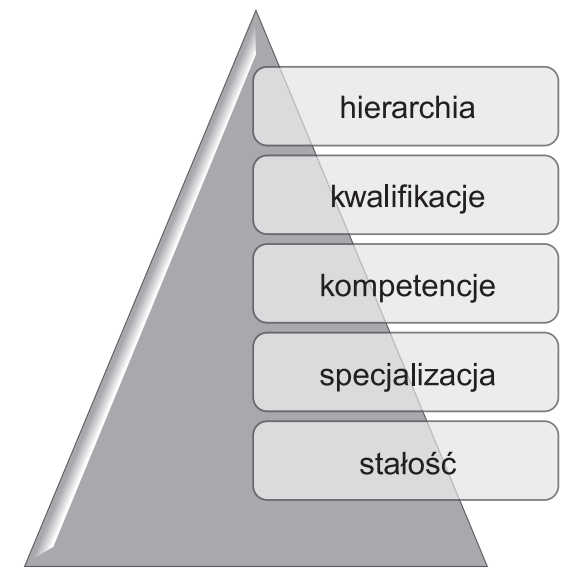

model Weberowski

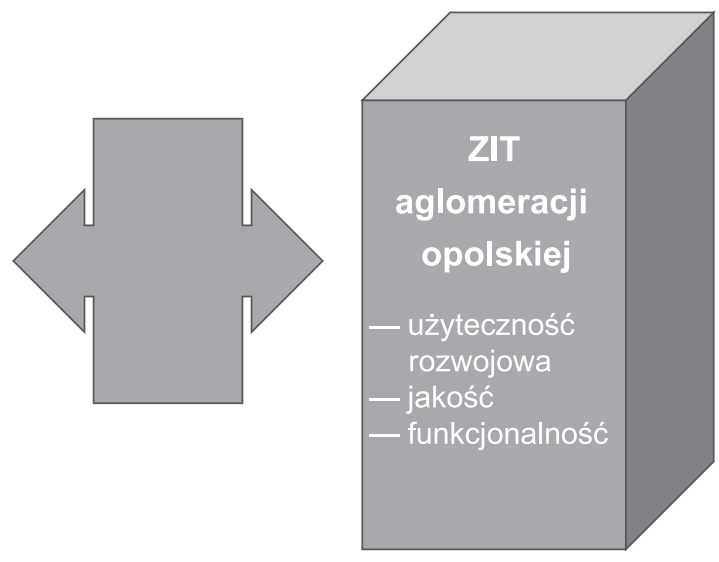

model badawczy ZIT

Rysunek 1. Model badawczy i identyfikacja luki badawczej opolskiego ZIT

Źródło: opracowanie własne.

Analiza opolskiego ZIT, jako instrumentu działania sektora publicznego, umożliwia wskazanie efektywności poprzez użycie korelacji pomiędzy modelem Weberowskim a modelem wdrażania opolskiego ZIT. Model Weberowski opiera się na modelu idealnego systemu zarządzania administracją publiczną ${ }^{29}$ i umożliwia analizę modelu wdrożeniowego opolskiej strategii ZIT ${ }^{30}$. Model opolskiej strategii ZIT, czyli swoisty profil obecnego i pożądanego stanu funkcjonowania, a zarazem i działania, wskazywać może na intencje użycia zintegrowanych działań służących rozwiązywaniu wspólnych dla całego obszaru funkcjonalnego problemów. Model badawczy ukazuje określone komponenty trwałości funkcjonowania i działania opolskiego ZIT: funkcjonalność instrumentu, jakość oraz

\footnotetext{
${ }^{28}$ Ibidem, s. 48.

29 W. Szumowski, Zarządzanie publiczne - próba systematyzacji koncepcji, „Nauki o Zarządzaniu. Management Sciences" 2014, nr 4 (21), s. 91.

30 M. Weber, Gospodarka i społeczeństwo: zarys socjologii rozumiejącej, Warszawa 2002, s. 159.
} 
użyteczność rozwojową. Obecny profil ukierunkowany jest na zwiększanie efektywności realizacji polityki spójności UE. Strategia opolskiego ZIT, tak jak pozostałych ZIT w regionach, jest realizowana w nowej perspektywie na lata 2014-2020. Model wdrażania opolskiego ZIT w korelacji do modelu Weberowskiego wskazuje na szereg styczności pod względem cech diagnostycznych, takich jak np. cecha stałości na podstawie uregulowań prawnych delegujących do wykonywania określonych czynności przez opolski ZIT (podpisanie porozumienia z 2012 o powstaniu stowarzyszenia AO). Natomiast w ujęciu specjalizacji jako cechy modelu Weberowskiego opolski model ZIT cechuje się wyodrębnieniem ze względu na określone działania, które są uwidocznione w porozumieniu w sprawie przekazania zadań o charakterze prorozwojowym w zakresie realizacji ZIT finansowanych w ramach Regionalnego Programu Operacyjnego Województwa Opolskiego na lata 2014-2020, zawartym pomiędzy Samorządem Województwa Opolskiego, Związkiem ZIT oraz Wojewódzkim Urzędem Pracy ${ }^{31}$. Cechą diagnostyczną jest model kompetencyjny, czyli efektywne wdrażanie instrumentów finansowych przez ZIT, jako narzędzi wspomagających osiągnięcie wyznaczonych celów. Sposób badania kompetencji powinien być analizą zakresu realizacji następujących zadań publicznych:

- stworzenia dogodnych warunków dla inwestycji generujących nowe miejsca pracy,

- zwiększenia efektywności energetycznej oraz wykorzystania odnawialnych źródeł energii w sektorze publicznym,

- poprawy jakości powietrza,

- rozwoju kompetencji kluczowych na rynku pracy,

- budowy ponadregionalnej rangi $\mathrm{AO}^{32}$.

Kwalifikacje można zdefiniować jako wiedzę i umiejętności, które są potrzebne do wykonywania powierzonych zadań publicznych. Poprzez odpowiednie wykorzystywanie ZIT można zniwelować zjawiska problemowe, np. tzw. inkluzję funkcjonalną, co jest istotą rozwoju tych obszarów. Natomiast hierarchia uwzględnia ostateczne zapisy strategii ZIT AO, co podporządkowane zostało ideom zawartym w dokumentach strategicznych szczebla unijnego i krajowego. Takie podejście wynika z założeń prowadzenia spójnej, unijnej polityki regionalnej.

\section{Podsumowanie}

Rozwój obszarów funkcjonalnych w ujęciu regionalnym wymaga w Polsce swoistego, wzmocnionego podejścia zintegrowanego na rzecz trwałości i ciągłości realizacji celów rozwojowych w układzie przestrzenno-społeczno-gospodarczym. Obecna architektura wsparcia rozwoju regionalnego wymaga wdrażania odpowiednich działań zintegrowanych, polegających na wsparciu i realizacji dalszych zmian kierunków rozwoju obszarów funkcjonalnych. Diagnoza sytuacji społeczno-gospodarczej województwa opolskiego wykazuje występowanie niekorzystnych zjawisk społeczno-gospodarczych. Zawarte

\footnotetext{
31 Strategia Zintegrowanych Inwestycji Terytorialnych Aglomeracji Opolskiej..., s. 11.

32 Ibidem, s. 13-16.
} 
$\mathrm{w}$ diagnozie obszary wsparcia $\mathrm{w}$ ramach strategii opolskiego ZIT obejmują: demografię, gospodarkę, rynek pracy, edukację, infrastrukturę techniczną, dostępność transportową, środowisko, turystykę i dziedzictwo kulturowe. Odpowiedzią na wyżej wymienione obszary problemowe w zakresie polityki regionalnej są ZIT, w których odchodzi się od ujęcia systemowego na rzecz podejścia zintegrowanego oraz znacznego usamodzielnienia się regionów z uwzględnieniem ich specyfiki.

Proponowane kierunki i obszary zmian w organizacji ZIT w województwie opolskim to stworzenie odpowiednich warunków sprzyjających jego rozwojowi. W odniesieniu do zaproponowanego modelu Weberowskiego oraz jego zastosowania w analizie wdrażania ZIT w AO można wskazać czynniki warunkujące ten rozwój. Należą do nich: użyteczność rozwojowa, jakość, funkcjonalność, wspomaganie publicznymi i unijnymi środkami w postaci wsparcia finansowego w ramach EFRR, który został utworzony w 1975 r., w celu wzmacniania spójności gospodarczej i społecznej UE poprzez korygowanie dysproporcji i dysharmonii między poszczególnymi regionami. Celem jest wyrównywanie szans i zmniejszanie luki rozwojowej (również poprzez zmniejszanie dysproporcji na poziomie krajowym-regionalnym-lokalnym) oraz powołanie sieci partnerstwa jako infrastruktury wspierającej i monitorującej obszary funkcjonalne. Dla przeciwwagi warto również wymienić bariery hamujące rozwój opolskiego ZIT. Zaliczyć do nich można młodą i słabo rozwiniętą organizację (pod względem kadrowym i strukturalnym), która może skutkować brakiem stabilizacji oraz niemożnością realizacji celów społeczno-gospodarczych. Dodatkowo wskazać należy niewystarczającą współpracę administracji publicznej z trzecim sektorem, co może obniżać efektywność realizacji zadań publicznych z udziałem opolskiego ZIT i powodować brak zaufania publicznego do inicjatyw trwałych, podejmowanych przez opolski ZIT, a w szczególności brak aktywnego zaangażowania społeczeństwa obywatelskiego. Natomiast młody i słabo rozwinięty model wdrożeniowy ZIT może przyczyniać się do niewłaściwych proporcji między realizacją celów społeczno-gospodarczych a efektywnością realizacji celów rozwojowych obszarów funkcjonalnych.

\section{Bibliografia}

Aghion P., Howitt P., Endogenous Growth Theory, MIT Press, Cambridge, 1997.

Barca F., Program dla zreformowanej polityki spójności. Podejście ukierunkowane terytorialnie w osiaganiu celów i oczekiwań Unii Europejskiej, Ministerstwo Rozwoju Regionalnego, Warszawa 2013.

Dumała A., Regiony międzynarodowe - synteza porównawcza, [w:] Regiony w stosunkach międzynarodowych, red. I. Topolski et al., Wydawnictwo Uniwersytetu Marii Curie-Skłodowskiej, Lublin 2009.

Europa 2020. Strategia na rzecz inteligentnego i zrównoważonego rozwoju sprzyjajacego włączeniu społeczne$m u$, KOM (2010) 2020 wersja ostateczna, Komisja Europejska, Bruksela, 3.3.2010.

Gorzelak G., Kozak M., Regionalny wymiar strategicznego programowania rozwoju, [w:] Zarządzanie strategiczne rozwojem, red. J. Górniak, S. Mazur, Ministerstwo Rozwoju Regionalnego, Warszawa 2012.

https://www.funduszeeuropejskie.gov.pl/strony/o-funduszach/dokumenty/rozporzadzenie-parlamentueuropejskiego-i-rady-ue-nr-13032013-z-dnia-17-grudnia-2013-roku-ustanawiajace-wspolne-przepisydotyczace-efrr-efs-fs-effrow-oraz-efmir/ (dostęp: 26 lutego 2017).

Koncepcja Przestrzennego Zagospodarowania Kraju 2030, dokument przyjęty przez Radę Ministrów 13 grudnia $2011 \mathrm{r}$. 
Regionalne Programy Operacyjne na lata 2014-2020, http://inteligentny-rozwoj.com.pl/index.php/fundusze-europejskie-2014-2020/regionalne-programy-operacyjne-2014-2020-rpo-2014-2020/ (dostęp: 16 września 2017).

Rozporządzenie Parlamentu Europejskiego i Rady (UE) nr 1301/2013 z dnia 17 grudnia 2013 r. w sprawie Europejskiego Funduszu Rozwoju Regionalnego i przepisów szczególnych dotyczących celu „Inwestycje na rzecz wzrostu i zatrudnienia" oraz w sprawie uchylenia rozporządzenia (WE) nr 1080/2006.

Rozporządzenie Parlamentu Europejskiego i Rady (UE) 1303/2013 z dnia 17 grudnia 2013 r. ustanawiające wspólne przepisy dotyczące Europejskiego Funduszu Rozwoju Regionalnego, Europejskiego Funduszu Społecznego, Funduszu Spójności, Europejskiego Funduszu Rolnego na rzecz Rozwoju Obszarów Wiejskich oraz Europejskiego Funduszu Morskiego i Rybackiego oraz ustanawiające przepisy ogólne dotyczące Europejskiego Funduszu Rozwoju Regionalnego, Europejskiego Funduszu Społecznego, Funduszu Spójności i Europejskiego Funduszu Morskiego i Rybackiego oraz uchylające rozporządzenie Rady (WE) $\mathrm{nr} 1083 / 2006$.

Rozporządzenie Parlamentu Europejskiego i Rady (UE) nr 1304/2013 z dnia 17 grudnia 2013 r. w sprawie Europejskiego Funduszu Społecznego i uchylające rozporządzenie Rady (WE) nr 1081/2006.

Strategia Zintegrowanych Inwestycji Terytorialnych Aglomeracji Opolskiej, Biuro Stowarzyszenia Aglomeracja Opolska, Opole 2015.

Strzelecki Z., Gospodarka regionalna i lokalna, PWN, Warszawa 2009.

Szafranek E., Zintegrowane inwestycje terytorialne jako narzędzie budowy potencjału obszarów funkcjonalnych. Przykład Kędzierzyńsko-Kozielskiego Subregionalnego Obszaru Funkcjonalnego, „Gospodarka Regionalna w Teorii i Praktyce" 2015, nr 392.

Szumowski W., Zarządzanie publiczne - próba systematyzacji koncepcji, „Nauki o Zarządzaniu. Management Sciences" 2014, nr 4 (21).

Ustawa z dnia 17 maja 1989 r. Prawo geodezyjne i kartograficzne, Dz.U. z 2005 r. Nr 240, poz. 2027, z późn. zm. Ustawa z dnia 27 marca 2003 r. o planowaniu i zagospodarowaniu przestrzennym, Dz.U. z 2012 r. poz. 647, poz. 951 i poz. 1445 oraz z 2013 r. poz. 21 i poz. 405.

Ustawa z dnia 6 grudnia 2006 r. o zasadach prowadzenia polityki rozwoju, Dz.U. 2006 Nr 227, poz. 1658.

Ustawa z dnia 11 lipca 2014 r. o zasadach realizacji programów w zakresie polityki spójności finansowanych w perspektywie finansowej 2014-2020, Dz.U. z 2014 r. poz. 1146.

Weber M., Gospodarka i społeczeństwo: zarys socjologii rozumiejacej, PWN, Warszawa 2002.

Zasady Realizacji Zintegrowanych Inwestycji Terytorialnych w Polsce, Ministerstwo Rozwoju Regionalnego, Warszawa 2013.

Zintegrowane działania na rzecz zrównoważonego rozwoju obszarów miejskich. Polityka spójności na lata 2014-2020, Komisja Europejska, Bruksela 2014.

\section{The importance of an integrated approach to functional areas in terms of regional - case study}

Keywords: integrated approach, development of functional areas, European Union regional policy

\section{Summary}

The aim of the article is to approximate the importance of an integrated approach to the development of functional areas in territorial policy. The concept of an integrated approach is presented in this paper to illustrate the importance of integrated public actions for the development of functional areas. A systematic analysis was used at the theoretical level to examine organizational conditions and to support the implementation of an integrated approach to the development of functional areas. A case study was used as a research method in the empirical level based on the analysis of the selected ZIT, to determine the method of implementing the integrated development of functional areas in the regional policy of the European Union. 